\title{
Strengthening District Health Care System through Partnership with Academic Institutions: The Social Accountability of Medical Colleges in Nepal
}

\author{
Magar A, ${ }^{1}$ Subba K² \\ 'Nepal Health Research Council, Kathmandu, Nepal, ${ }^{2}$ xenoMED Foundation, Kathmandu, Nepal.
}

\section{ABSTRACT}

Approximately $25-30 \%$ of the Nepalese population live below poverty line. Majority of them reside in a geographically inaccessible place while most of the health centers are focused in the urbanized cities of Nepal. Hence, they are deprived of quality health care at that level and need urgent attention by the concerned authorities. The government has not increased its human resource for health in the last two decades, while population has doubled up but the number of doctors serving in public sectors has remained the same as it was in 1990s.

We have got 19 medical colleges at the moment. If one district is allocated to each medical colleges, it could help improve district health system at local level in Nepal. This can be accomplished by posting postgraduate resiendts in the peripheral district hospital as a part of their training and later encouraging them to serve for certain years. This could be a perfect example of government envisioned public private partnership in the country. This is a concept that has already been started in many parts of the world that can be moulded further to improve health service at peripheral part of the country. It is also the social accountability of the medical colleges for the development of the nation.

Keywords: district health care system; medical education; social accountability.

\section{INTRODUCITON}

The health system of Nepal is based on the Alma Atta declaration ${ }^{1,2}$ and has a good networking of infrastructure starting from sub health post to primary health care center, district hospitals, zonal, regional hospital and tertiary care hospital at central level. Despite of which most of our people do not have access to essential primary health services. There are many reasons such as methods of health service delivery,

Approximately $25-30 \%$ of the Nepalese population live below poverty line. Majority of them reside in a geographically inaccessible place while most of the health centers are focused in the urbanized cities of Nepal. Hence, they are deprived of quality health care at that level and need urgent attention by the concerned authorities. The government has not increased its human resource for health in the last two decades, while population has doubled up and the number of doctors serving in public sectors has remained the same as it was in 1990s. On the other hand productions of doctors have increased by many folds due to establishment of number of medical colleges in the country. But the social accountability $(S A)^{3-5}$ has not been felt in the majority of stakeholders in Nepal. SA in health professions is increasingly recognized as a foundation for delivering effective healthcare. ${ }^{6}$ Beside this, there has been evaluation of this concept which addresses many key aspects of its successful implementations. ${ }^{7-10}$

WHO country office Nepal is keen to support and facilitating this concept. As the global consensuses on social accountability of medical schools are rising, ${ }^{11,12}$ even seeking impact of medical schools on health, ${ }^{6,13}$ Nepal is not far behind. There has been meetings and workshops, being conducted to sensitize and make aware policy makers and concerned stakeholders. The Nepal Medical Council (NMC), Nepal Medical Association (NMA), Association of Private Medical and Dental Colleges of Nepal (APMDC), Department of Health Services (DoHS), Ministry of Education (MoE), Ministry of Health and Population (MoHP), National Planning Commission (NPC) with concerned

Correspondence: Dr. Angel Magar, Nepal Health Research Council, Ramshah Path, P.O. Box 7626, Kathmandu, Nepal. Email: ang2el@gmail.com, Phone: 4254220. 
stakeholders and external donor partners (EDPs) such as World Health Organization (WHO) and above all political will power, need to materialize this concept in Nepal (Figure 1). Ministry of Health and Population has to take a complete lead to initiate SA in the part of medical colleges in Nepal.

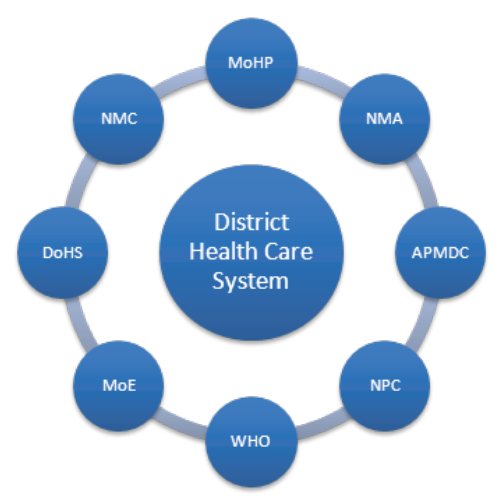

Figure 1. Key Stakeholders for Strengthening District Health Care System.

\section{SOCIAL ACCOUNTABLITY}

According to WHO the SA of medical schools is the obligation to direct their education, research and service activities towards addressing the priority health concerns of the community, region, and/or nation they have a mandate to serve. These priority health concerns are to be identified jointly by governments, health care organizations, health professionals and the public. ${ }^{14} \mathrm{SA}$ is gaining momentum throughout the globe to ensure quality health service at local level. ${ }^{15-18}$

With the social accountability of medical schools, challenges $^{6,13,19}$ also arise for undergraduate and postgraduate programs expanding beyond its traditional tertiary care models. Critical areas of attention include the institutional culture, human, physical and financial resources, and support for educational activities. Therefore, to come out with thriving integrated community-engaged medical education programs need detail homework, ranging from funding models to educational environment. The ultimate goal should be a successful integration of university and accreditation ideals with practical hands-on medical care and education in new environments as envisioned in Northern Ontario. ${ }^{20}$

The beginning of the 20th century presented medical schools with unprecedented challenges to become more scientific and effective in the training of physicians. This was captured in the Flexner report of 1910. ${ }^{21}$ The $21^{\text {st }}$ Century presents medical schools with a different set of challenges: improving quality, equity, relevance and effectiveness in health care delivery; reducing the mismatch with societal priorities; redefining roles of health professionals; and providing evidence of impact on people's heath status. ${ }^{22}$

Global Consensus for Social Accountability of Medical Schools advocates to reorient medical school education, research and service priorities accordingly, strengthen governance and partnerships with other stakeholders, use evaluation and accreditation to assess performance and impact with its strategic directions. ${ }^{22}$

The oldest medical colleges in the country - Institute of Medicine (IOM) and BP Koirala of Health Sciences (BPKIHS) have certain part of curriculum for community field work for its medical students. Whereas, Patan Academy of Health Science (PAHS) has been established with the concept of producing local doctors by sending back to the community for certain years before they get their certificate. Many rural regions around the world for example, Northern Ontario has a chronic shortage of doctors; recognizing that medical graduates who have grown up in a rural area are more likely to practice in the rural setting, the Government of Ontario, Canada, decided in 2001 to establish a new medical school in the region with a social accountability mandate to contribute to improving the health of the people and communities. $^{23}$

Overseas elective opportunities have been made available in Nepal as elsewhere to provide opportunities to experience health services at poor, resource constrain area. ${ }^{19}$ Many medical colleges have been accpeting elective students in the country.

On the other hand, numbers of medical and nursing schools have established in last two decades. This is a high time for the government to build a partnership with private sector to strengthen its health services. One possible approach would be to Strengthening of District Health Care System through Partnership with Academic Institutions in Nepal. Preliminary brain storming and a workshops have also been conducted. This initiation need to be further discussed and implemented. SA has been a discussions ${ }^{24-30}$ in todays' world to produce socially responsible doctors as well. ${ }^{31-35}$

\section{MEDICAL COLLEGES IN NEPAL}

There are 19 medical and 11 dental colleges (Table 1). Ironically, out of 75 districts, we have 22 low human development index (HDI) districts in the country. Most of these medical colleges have 500-700 beds in the hospital and, usually the bed occupancy is always $<60 \%$. Altogether 7,140 medical students are studying as of early 2011, out of which $\sim 220$ students are allocated for government scholarship holders each year (Table 2). 
Table 1. Medical and Dental Colleges in Nepal.

\begin{tabular}{|c|c|c|}
\hline SN & Medical Colleges & Dental Colleges \\
\hline & Institute of Medicine (IOM)* & Peoples Dental College \\
\hline & B.P. Koirala Institute of Health and Sciences* & Kantipur Dental College \\
\hline & Manipal College of Medical Sciences*,$\ddagger$ & MB Kedia Dental College \\
\hline & College of Medical Sciences ${ }^{*}, \ddagger$ & \\
\hline & Nepal Medical College ${ }^{*}, \dagger$ & \\
\hline & Kathmandu Medical College* & \\
\hline & Nepalgunj Medical College* & \\
\hline & Universal College of Medical Science ${ }^{*}, \dagger, \ddagger$ & \\
\hline & Kathmandu University, School of Medical Sciences* & \\
\hline & National Medical College* & \\
\hline & Janaki Medical College & \\
\hline & National Academy of Medical Sciences (NAMS) || & \\
\hline & Nobel Medical College* & \\
\hline & Kist Medical College§ & \\
\hline & Lumbini Medical College \& Research Center Pvt. Ltd. § & \\
\hline & Chitwan Medical College $\S$ & \\
\hline & Patan Academy of Health Sciences§ & \\
\hline & Gandaki Medical College§ & \\
\hline & Nepalese Army Institute of Health Sciences§ & \\
\hline
\end{tabular}

*MBBS + PG education, †BDS also, ¥Medical colleges with foreign investments, §MBBS only, ||Post graduate only.

Table 2. Distribution of MBBS Students in Nepal as of early 2011.

\begin{tabular}{|c|c|c|c|c|c|c|}
\hline Medical College & MBBS I & MBBS II & MBBS III & MBBS IV & Intern & Total \\
\hline 1. Institute of Medicine & 60 & 60 & 61 & 61 & 59 & 301 \\
\hline $\begin{array}{l}\text { 2. B.P. Koirala Institute of Health and } \\
\text { Sciences }\end{array}$ & 100 & 100 & 100 & 100 & 80 & 480 \\
\hline 3. Manipal College of Medical Sciences. & 130 & 120 & 188 & 153 & 65 & 656 \\
\hline 4. College of Medical Sciences & 150 & 150 & 150 & 150 & 150 & 750 \\
\hline 5. Nepal Medical College & 100 & 85 & 101 & 97 & 66 & 449 \\
\hline 6. Kathmandu Medical College & 110 & 100 & 75 & 75 & 99 & 459 \\
\hline 7. Nepalgunj Medical College & 150 & 150 & 150 & 150 & 150 & 750 \\
\hline 8. Universal College of Medical Science & 150 & 150 & 150 & 150 & 150 & 750 \\
\hline $\begin{array}{l}\text { 9. Kathmandu University, School of } \\
\text { Medical Sciences }\end{array}$ & 60 & 60 & 61 & 45 & 45 & 271 \\
\hline 10. National Medical College & 150 & 150 & 150 & 150 & 100 & 700 \\
\hline 11. Janaki Medical College & 100 & 100 & 100 & 100 & 100 & 500 \\
\hline 12. Nobel Medical College & 150 & 150 & 150 & 100 & & 550 \\
\hline 13. Kist Medical College & 100 & 100 & 75 & & & 275 \\
\hline $\begin{array}{l}\text { 14. Lumbini Medical College \& Research } \\
\text { Center Pvt. Ltd. }\end{array}$ & 100 & 60 & 36 & & & 196 \\
\hline 15. Chitwan Medical College & 100 & 100 & & & & 200 \\
\hline 16. Patan Academy of Health Sciences & 60 & 60 & & & & 120 \\
\hline 17. Gandaki Medical College & - & - & - & - & - & - \\
\hline 18. NAIHS - College of Medicine & 100 & - & - & - & - & 100 \\
\hline $\begin{array}{l}\text { 19. National Academy of Medical } \\
\text { Sciences* }\end{array}$ & - & - & - & - & - & - \\
\hline Total & & & & & & 7147 \\
\hline
\end{tabular}

*Post-Graduate Study only. 


\section{PUBLIC PRIVATE PARTERNSHIP}

The Strengthening of District Health Care System through Partnership with Academic Institutions in Nepal can be achieved by various approaches. One of them could be, by posting postgraduate resiendts in the peripheral district hospital as a part of their training and later encouraging them to serve for certain years or sending medical graduate to the community. It will help them associate with the villegers that, in turn, will help them become socially responsible doctors. This would also result in improving health care at the district level, diminishing unnecessary referrals and supplement with affordable health service at local level (Figure 2).

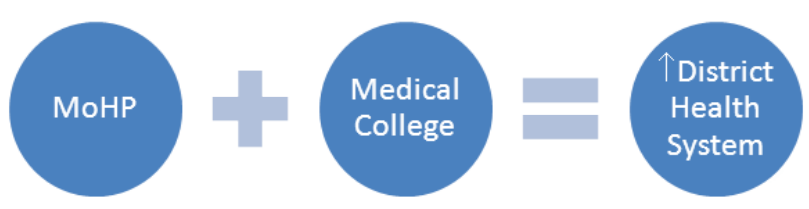

Figure 2. Strengthening of District Health Care System through Partnership with Academic Institutions.

The concept of partnership has been a declared modality of the government under all agencies of the government of Nepal. Realizing the importance of social accountability, if these medical colleges would help at least one district, we are likely to have improved health services in that region. With this public private partnership concept, both the stakeholders will be mutually benefitted by the association because, if a district hospital is supported by the medical college not only the health service will improve but others as well, such as;

- Academic Activities beyond Classroom: Medical College can produce competent, more socially responsible future doctors by providing opportunity to interact with community through their regular posting and community based exposure. The community based continue medical education (CME) will also provide them various opportunity to learn about own country's need and requirement and intervention to diminish morbidity and mortality.

- Disaster and Epidemics: the government can tackle the adverse situation during crisis by mobilizing these health workers in the affected site, quickly.

- Strengthen Referral Service: When a district hospital improves its services, it can act as a referral center for that entire district and poor patient do not have to go far away with an extensive financial burden for minor ailments.
- Effectiveness and Efficiency in Health Services: With the added human resource with academically competent doctors, all the essential health service coverage will increase.

- Specialty Services at Periphery: These district hospitals can also provide specialty care at the peripheral part of the country by conducting regular outreach clinics.

- Social Accountability: There are social accountabilities of medical colleges to provide their services to the neediest people in the country as well.

- Risk and Resource Sharing: It will be a mutually benefitted public and private partnership, where risk and resource are shared for the development of the nation.

\section{CHALLENGES}

This PPP will be mutually advantageous for government and medical colleges in the long run. However, there are few challenges as follows:

- Variations in Existing Models: BPKIHS has a teaching district concept, whereas in MoHP scholarship model, scholarship holders have to serve mandatory 2 year in the government service. IOM community diagnosis is limited to only the basic years of medical schooling. The PAHS has come up with the new models of sending its graduates to the districts (except those who are self-finance), a little advance version of scholarship model with modified curriculum where it provides more community exposure to its students. Because of variations in the eixisting models either we have to adopt one of these or make hybride or create completely new, according to our need, has to be discussed in detail.

- Infrastructures: District hospitals are made for the purpose of service provision but once it is tied up with a medical college, many things need to be improved, from physical infrastructure to the management and administration of the hospital. The class rooms, residential quarters, added service delivery areas, robust hospital management team and governance with minimum dispute between government and medical college employees.

- Finance: with an additional responsibility and service provision, there is always a role of finance. Will the government pay lump sum amount on annual basis to the medical colleges or not, tax deduction and various other benefits to the medical colleges to motivate them to work more efficiently will be the 
key issues. The certain bulk amount can be given to a medical college or mutually benefitted approach has to be developed.

- Curriculum Reform: TU, BPKIHS, KU, PAHS and NAMS have with their own curriculums. It needs to be revised according to a new national policy with the concept of strengthening district health service care system.

- Professional Organizations: The role of NMC, NMA, APMDC, and other concerned organizaitons is also very important to formulate new policy in the guidelines for its undisputed acceptance. The NMA has always been instrumental to shape the health care system in the country; therefore, their role to advocate on this issue becomes even more important.

Despite all these challenges, we have our social responsibility towards development of the nation. There are various model and thoughts throughout the world but we have to develop according to our own needs. We need to improve the health service delivery in the districts and enhance learning skill and produce socially responsible future doctors in the country.

\section{WAY FORWARD}

The Strengthening of District Health Care System through Partnership with Academic Institutions in Nepal is a vision that needs detail homework with concerned stakeholders. This cannot be achieved in a day rather it is a road map to a better health that requires dedicated team of people lead by MoHP. It is possible, if government shows commitment to improve health service at peripheral part of the country. A high level committee has to be formed that would work closely with concerned stakeholders for continuous brain storming, and dialogues. An in depth discussions are essential to formulate a long term sustainable program. The consensus from universities, NMC, NMA, APMDC, NPC, DoHS, MoE, MoHP, WHO has to be made and included in the central governing body.

When a complete picture of strengthening district health care system is portrayed then a planned, phase-wise program has to be started beginning with a pilot project with highly motivated medical college and districts health centers. To start with, postgraduate student can be posted in the peripheral district hospital during their early days of final years. During the initial phase, logistic can be provided by district hospitals while human resource by medical college; this association can provide quality health services at local level. This approach will help the local people to get improve health care. The periodic monitoring and evaluation of the program has to be done for it efficacy and short comings.

We have got 19 medical colleges at the moment. If one district is allocated to each medical colleges, it could help improve district health system at local level. This can be accomplished by posting postgraduate resiendts in the peripheral district hospital as a part of their training and later encouraging them to serve for certain years. This could be a perfect example of government envisioned public private partnership in the country. This is a concept that has already been started in many parts of the world that can be moulded further to improve health service at peripheral part of the country. It is also the social accountability of the medical colleges for the development of the nation.

This concept can help improve health services at peripheral level and would also meet the need of true meaning of de-centralization in the country.

\section{REFERENCES}

1. Primary Health Care. Report of the International Conference on Primary Health Care Ama-Ata, USSR, 6-12 September 1978 Geneva: WHO; 1978 [cited 2011 Dec 25]. Available from: http://whqlibdoc.who.int/publications/9241800011. pdf.

2. Declaration of Alma-Ata. International Converence on Primary Health Care, Alma-Ata, USSR, 6-12 September 1978 USSR: WHO; 1978 [cited 2011 Dec 25]. Available from: http://www.who.int/publications/almaata_declaration_ en.pdf.

3. Woollard RF. Caring for a common future: medical schools' social accountability. Med Educ. 2006 Apr;40(4):301-13. PMID: 16573665.
4. Gibbs T, McLean M. Creating equal opportunities: the social accountability of medical education. Med Teach. 2011;33(8):620-5. PMID: 21774647.

5. Hennen B. Demonstrating social accountability in medical education. CMAJ. 1997 Feb 1;156(3):365-7. PMID: 9033418.

6. Ho K, Buote D, Jarvis-Selinger S, Lauscher HN, Ferdinands $\mathrm{L}$, Parboosingh J, et al. Achieving social accountability through interprofessional collaboration: the Canadian medical schools experience. J Interprof Care. 2008;22 Suppl 1:4-14. PMID: 19005950.

7. Leinster S. Evaluation and assessment of social accountability in medical schools. Med Teach. 2011;33(8):673-6. PMID: 21774656 . 
8. Goldman J, Reeves S, Lauscher HN, Jarvis-Selinger S, Silver I. Integrating social accountability into continuing education and professional development at medical schools: the case of an institutional collaborative project in Canada. J Interprof Care. 2008;22 Suppl 1:40-50. PMID: 19005953.

9. Gonnella JS, Hojat M. Medical education, social accountability and patient outcomes. Med Educ. 2012 Jan;46(1):3-4. PMID: 22150187.

10. Thompson LG, Davis PM. Best medical practices in social accountability and continuing professional development: a survey and literature review. J Interprof Care. 2008;22 Suppl 1:30-9. PMID: 19005952.

11. Boelen C. [Global consensus on social accountability of medical schools]. Sante Publique. 2011 May-Jun;23(3):247-50. PMID: 21896218.

12. Hoppe JD. [The medical profession and social accountability. Opening address at the 103. German Doctors' Day in Cologne, May 9, 2000]. Internist (Berl). 2000 Sep;41(9):M201-5. PMID: 11041696.

13. Woollard B, Boelen C. Seeking impact of medical schools on health: meeting the challenges of social accountability. Med Educ. 2012 Jan;46(1):21-7. PMID: 22150193.

14. Boelen C, Heck J. Defining and measuring the social accountability of medical schools Geneva: World Health Organization; 1995 [cited 2011 May 20]. Available from: http:/ / apps.who.int/iris/bitstream/10665/59441/1/ WHO_HRH_95.7.pdf.

15. Gadon M, Glasser M. Medical professionalism and social accountability in medical education. Educ Health (Abingdon). 2006 Nov;19(3):287-8. PMID: 17178510.

16. Worley P, Murray R. Social accountability in medical education--an Australian rural and remote perspective. Med Teach. 2011;33(8):654-8. PMID: 21774653.

17. Lindgren S, Karle $\mathrm{H}$. Social accountability of medical education: aspects on global accreditation. Med Teach. 2011;33(8):667-72. PMID: 21774655.

18. Boelen C. Social Accountability: Medical Education's Boldest Challenge. MEDICC Rev. 2008 Oct;10(4):52. PMID: 21483336.

19. Murdoch-Eaton D, Green A. The contribution and challenges of electives in the development of social accountability in medical students. Med Teach. 2011;33(8):643-8. PMID: 21774651.

20. Topps M, Strasser R. When a community hospital becomes an academic health centre. Can J Rural Med. 2010 Winter;15(1):19-25. PMID: 20070926.

21. Flexner A. Medical Education in the United States and Canada: A Report to the Carnegie Foundation for the Advancement of Teaching. Bulletin No. 4 New York City: The Carnegie Foundation for the Advancement of Teaching; 1910 [cited 2011 Sep 07]. Available from: http://www. carnegiefoundation.org/sites/default/files/elibrary/ Carnegie_Flexner_Report.pdf.
22. Global Consensus for Social Accountability of Medical Schools [cited 2011 Dec 21]. Available from: http:// healthsocialaccountability.org/.

23. Strasser RP, Lanphear JH, McCready WG, Topps MH, Hunt DD, Matte MC. Canada's new medical school: The Northern Ontario School of Medicine: social accountability through distributed community engaged learning. Acad Med. 2009 Oct;84(10):1459-64. PMID: 19881443.

24. Adli M, Kleinert S, Smith SK, Ganten D. Academic medicine must take its global role: the M8 Alliance of Academic Health Centers and Medical Universities. Lancet. 2010 Oct 9;376(9748):1197-8. PMID: 20934578.

25. Mayer ES. Academic support for rural practice: the role of area health education centers in the school of medicine. Acad Med. 1990 Dec;65(12 Suppl):S45-50. PMID: 2252518.

26. Gazewood JD, Rollins LK, Galazka SS. Beyond the horizon: the role of academic health centers in improving the health of rural communities. Acad Med. 2006 Sep;81(9):793-7. PMID: 16936482.

27. Koh HK, Shei AC, Bataringaya J, Burstein J, Biddinger $\mathrm{PD}$, Crowther MS, et al. Building community-based surge capacity through a public health and academic collaboration: the role of community health centers. Public Health Rep. 2006 Mar-Apr;121(2):211-6. PMID: 16528956.

28. Osborn LM, Kotrady K. The changing role of academic health care centers in generalist education and practice support. J Gen Intern Med. 1994 Apr;9(4 Suppl 1):S72-80. PMID: 8014748.

29. Kassebaum DG. Coming to terms with the nursing shortage--asserting the role and initiatives of academic health centers. Acad Med. 1989 Feb;64(2):83-4. PMID: 2917039.

30. Morris AL, Hastings DA, Crispell KR. The dental school's role in academic health centers: report of a study. J Dent Educ. 1980 Dec;44(12):697-704. PMID: 6934200.

31. Zerzan JT, Gibson M, Libby AM. Improving state Medicaid policies with comparative effectiveness research: a key role for academic health centers. Acad Med. 2011 Jun;86(6):695-700. PMID: 21512359.

32. Rask KJ, Brigham KL, Johns MM. Integrating comparative effectiveness research programs into predictive health: a unique role for academic health centers. Acad Med. 2011 Jun;86(6):718-23. PMID: 21512361.

33. Murray RB, Larkins S, Russell H, Ewen S, Prideaux D. Medical schools as agents of change: socially accountable medical education. Med J Aust. 2012 Jun 4;196(10):653. PMID: 22676883.

34. Wartman SA, Steinberg MJ. The role of academic health centers in addressing social responsibility. Med Teach. 2011;33(8):638-42. PMID: 21774650.

35. Roper WL, Newton WP. The role of academic health centers in improving health. Ann Fam Med. 2006 Sep-Oct;4 Suppl 1:S55-7; discussion S8-60. PMID: 17003165. 